\title{
Diet composition of freshwater crab, Potamon koolooense Rathbun, 1904 from hillstream of Uttarakhand
}

\author{
S. N. Bahuguna ${ }^{1 *}$, Anita Rawat Rana ${ }^{2}$ and Shurveer Singh ${ }^{1}$ \\ ${ }^{1}$ Department of Zoology and Biotechnology, H.N.B. Garhwal University, Srinagar, Garhwal-246174 \\ (Uttarakhand), INDIA \\ ${ }^{2}$ Department of Zoology, Govt. P.G. College, Rishikesh, Dehradun-249201 (Uttarakhand), INDIA \\ *Corresponding author. E-mail: profsnbahuguna @ reddifmail.com
}

Received: June 18, 2015; Revised received: October 19, 2015; Accepted: February 29. 2016

\begin{abstract}
The present study was carried out to study the diet composition of freshwater crab, $P$. koolooense in hillstream Khoh of Uttarakhand during November, 2013 to October, 2014. Total 105 crab samples were used for the study, 35 male and 47 female were found with food in their stomach while rest of the 23 had empty stomachs. The carapace length $(\mathrm{CL})$ ranged from $12 \mathrm{~mm}$ to $49 \mathrm{~mm}$, carapace width (CW) from $15 \mathrm{~mm}$ to $59 \mathrm{~mm}$ and total weight (TW) from $2.08 \mathrm{~g}$ to $60.12 \mathrm{~g}$. Stomach content analysis of the animal showed that the diet of the animal composed of animal matter, plant matter, algae, fungi, debris and unidentified materials. Animal matter ranged from (3.27-11.93\%), plant matter (4.37-14.44\%), algae (1.73-6.15\%), fungi (0.17-1.43\%), debris $(28.18-40.47 \%)$ and unidentified materials (36.46-50.05\%) in males while in the female animal matter ranged from (3.09-12.34\%), plant matter (4.45$12.73 \%)$, algae (1.03-7.61\%), fungi (0.02-3.34\%), debris $(23.18-43.34 \%)$ and unidentified $(30.31-51.04 \%)$. Unidentified materials recorded maximum and fungi recorded minimum in both the sexes of Potamon koolooense. A significant difference was observed at $p<0.05$ between food groups- algae and unidentified matter in both sexes. This is the first report, to key out and quantifies the dietary items and feeding habits of crab in Uttarakhand which would be helpful in interpreting the ecological niche of the animal in mountain stream communities.
\end{abstract}

Keywords: Diet components, Freshwater crab, Hillstream, Khoh, Uttarakhand

\section{INTRODUCTION}

Food is most important for any living organism and the body also requires a range of nutrition to keep certain organs alive and to keep the correct balance in the body. This nutrition is taken from the food. The distribution, growth, reproduction, behaviour and migration rate of crabs are largely dependent on the availability of preferred prey organisms (Vinagre et al., 2007).

Crabs consume a great variety of food and there are many modes of feeding. Stomach content analysis has been used to investigate the diet of brachyuran crabs, mainly those belonging to the Grapsoidae, Portunidae and Majidae (Bernardez et al., 2000) but there is little information available regarding the feeding preferences of the Potamidae, regardless of the large number of potamid species in tropical and subtropical freshwater environments (Yeo et al., 2008). The analysis of stomach contents of crab provides information about particular the crab in the ecosystem. A large number of studies have been done on marine crabs by Patel et al. (1979), Chande and Mgaya (2004) and Josileen (2011) in relation to many aspects, but fewer studies have been done on freshwater crabs by Williner and Collins (2013); Kobayashi (2012). Knowledge of an animal's dietary habit is essential for studies of nutritional re- quirements, interactions with other organisms and for its aquaculture practice.

$P$. koolooense, a potamid crab usually inhabits the freshwater bodies e.g. rivers, streams, canals, lakes and ponds etc., found under the stones, logs and dead leaves, grassy vegetation, lives in burrows along the bank of the river and in the crevices of rocks. It plays an important role as a scavenger in the aquatic ecosystem. Like other brachyuran crabs, it has the same mouth structure for feeding. Examining the food and feeding habits or diet composition of crab is obviously considered very important in crustacean biology and ecological studies of crabs. As there is no information on diet composition of crab $P$. koolooense till date. Therefore an attempt has been made to study the dietary components of this animal.

\section{MATERIALS AND METHODS}

For the present study, monthly samples of crab were collected with the help of a fisherman during November 2013 to October 2014 from hillstream Khoh in district Pauri Garhwal Uttarakhand. The study area lies between $25^{\circ} 45^{\prime}$ to $30^{\circ} 15^{\prime}$ latitude and $78^{\circ} 24^{\prime}$ to $79^{\circ} 23^{\prime}$ longitude. Samples were brought from study sites to the laboratory where their carapace length, width were measured with the help of vernier calliper and weight 
taken in grams by electronic digital balance. Stomach content was taken out from the crab by operating it from dorsal side and a little water was added to it so as to make suspension of food material. The suspension was taken into the Sedge wick rafter chamber with micropipette followed by covering with a cover slip and examined under the Nikon ECLIPSE TS100 inverted binocular microscope. The food materials were then identified with the aid of keys provided by Needham and Needham (1962); Ward and Whipple (1959). Average number of each food item was calculated and converted into contributing percentage to the total food content by the formula

Where,

Percent by number, $\mathrm{N}=\left(\mathrm{N}_{\mathrm{i}} / \mathrm{N}_{\mathrm{t}}\right) \times 100$

$\mathrm{N}_{\mathbf{i}}=$ Number of food category $\mathbf{i}$ and

$\mathrm{N}_{\mathrm{t}}=$ Total number of food particles

Observed data were subjected to SPSS software version 16.0 for statistical analysis.

\section{RESULTS AND DISCUSSION}

Crabs occupy different niches and inhabit many different habitats in a variety of geographical areas and this is reflected in the variety of food consumed by them (Bryceson and Massinga, 2002). Our study included total 105 crabs, out of them 35 males and 47 females were found with food in their stomach while the rests 23 were with empty stomach. The carapace length (CL) ranged from $12 \mathrm{~mm}$ to $49 \mathrm{~mm}$, carapace width (CW) from $15 \mathrm{~mm}$ to $59 \mathrm{~mm}$ and total weight (TW) from $2.08 \mathrm{~g}$ to $60.12 \mathrm{~g}$. Stomach content analysis in both sexes of $P$. koolooense showed that the diet composed of animal matter, plant matter, algae, fungi, debris and unidentified materials (Plate 1).

Average quantity of different food components in male were animal matter $(6.76 \pm 2.5 \%)$, plant matter $(9.29 \pm 2.51 \%)$, algae $(3.12 \pm 1 \%)$, fungi $(0.72 \pm 0.33 \%)$, debris $(34.67 \pm 2.79 \%)$ and unidentified $(44.97 \pm 3.07 \%)$ while the average quantity of different food components in female were animal matter $(7.09 \pm 2.42 \%)$, plant matter $(9.13 \pm 2.1 \%)$, algae $(3.74 \pm 1.52 \%)$, fungi $(0.85 \pm 0.59 \%)$, debris $(34.41 \pm 4.06)$, and unidentified $(42.61 \pm 5.39 \%)$ that contributed to the total food contents consumed by the animal (Table 1).

The unidentified material was observed maximum and fungi was recorded minimum in both sexes during the study. A large amount of unidentified material was found in the stomach was the result of an advanced digestion degree. Crustacean jaws and gastric mills provide food triturating. This action makes the food material an unidentified mass item and suggests that these crabs present a high digestive ratio. The study showed that the animal is capable of ingesting both plant and animal matter along with dead and decaying matter that indicated the omnivorous nature of the animal. This is in agreement with Devi et al. (2013) as they observed $V$. litterata, herring bow crab was a predatory omnivore capable of ingesting both animal and plant tissues. The similar opportunistic omnivorous nature of painted pebble crab, Leucosia anatum was found by Varadharajan and Pushparajan (2012) in their study. The study also revealed that the animal is a bottom feeder because examination of stomach contents of the animal showed that the deposit feeding method was more usual.

It was based on the fact that percentage of debris, including sand particle, clay was always observed in considerable amount in the stomach of both sexes irrespective of size. It suggests the sandy and muddy substratum of the habited area. Our results got support from the study of Chatterjee (2014) as they had recorded $O$. macrocera, $D$. blanfordi and $D$. brevitarsis were exclusively deposit feeders and omnivores due to the maximum occurrence of sand particles, algae and detritus in their stomach. A significant difference was observed for food groups algae and unidentified material while the other food groups viz. animal matter, plant matter and debris were not statistically different at $\mathrm{p}<0.05$ in both sexes (Table 1). Neither the quantity of food nor the food components were significantly different in males and females except unidentified matter and algae, which may be different due to selective feeding at some stages of life. Viswanathan and Raffi (2015) also observed no significant difference between the quantity of food consumed by males and females except slight variations in mud crab $S$. Olivacea. The different constituents of food more or less same, this evidences the same feeding habits of male and female probably due to the fact that they dooccur in the same regions. Identical food preference and intake pattern were also reported by Mohapatra $e t$ al. (2005) in male and female of S. serrata. Observations on average amount of feeding in both-sexes showed that for some food groups males exhibit a little higher feeding intensity than females and vice versa. This may be due to changes in diet and feeding habits during their growth period from juveniles to adults. This was the first and a preliminary study of food and feeding habits of $P$. koolooense in the study region, more investigations are needed to complete the paucity of the present study and to understand the actual position of the animal in the ecosystem.

\section{Conclusion}

From the present study, it was concluded that Potamon koolooense was omnivorous in nature and bottom feeder. It feeds on whatever is present in their surroundings and rarely feeds selectively at some stages during their life cycle. Diet components were almost same in both sexes and composed of animal matter, plant matter, algae, fungi, debris and unidentified matter. Among identified food components debris formed the major food component followed by plant matter. This is the first report, to key out and quantifies the diet items and feeding habits of crab in Uttarakhand which would be helpful in interpreting the ecological 


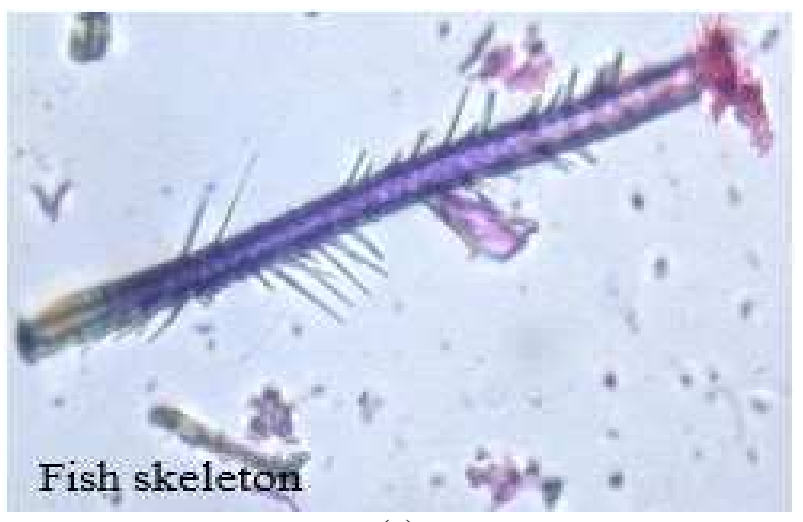

(a)

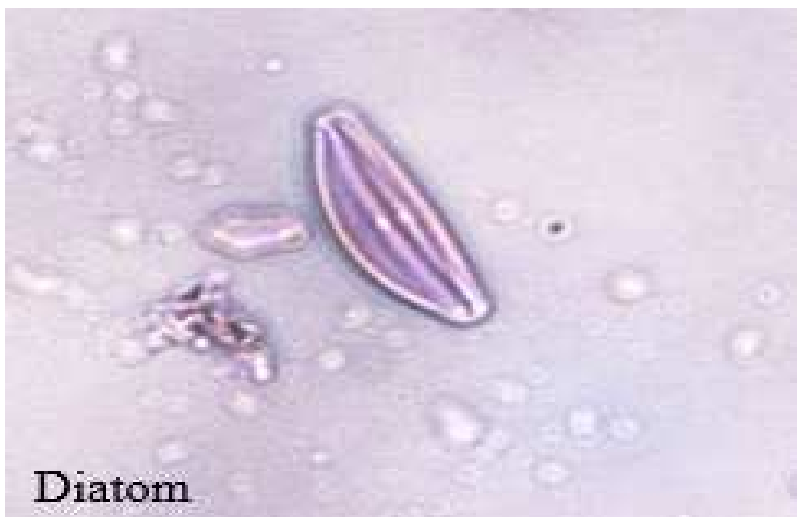

(c)

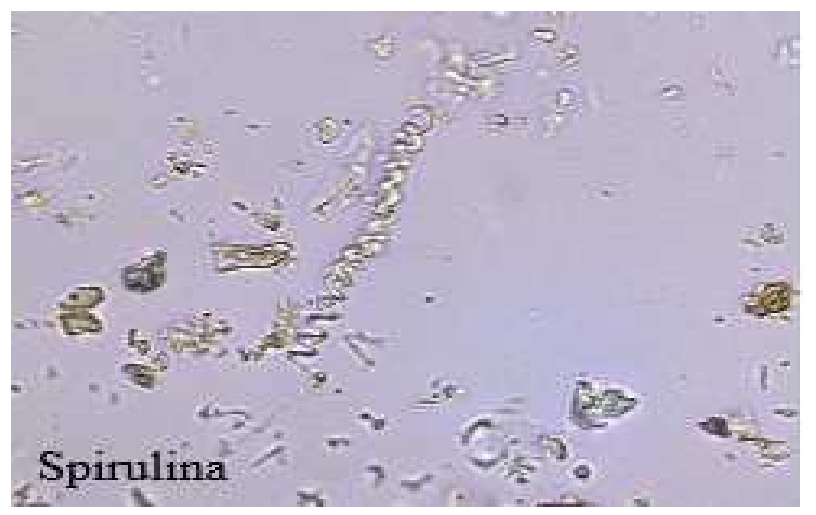

(e)

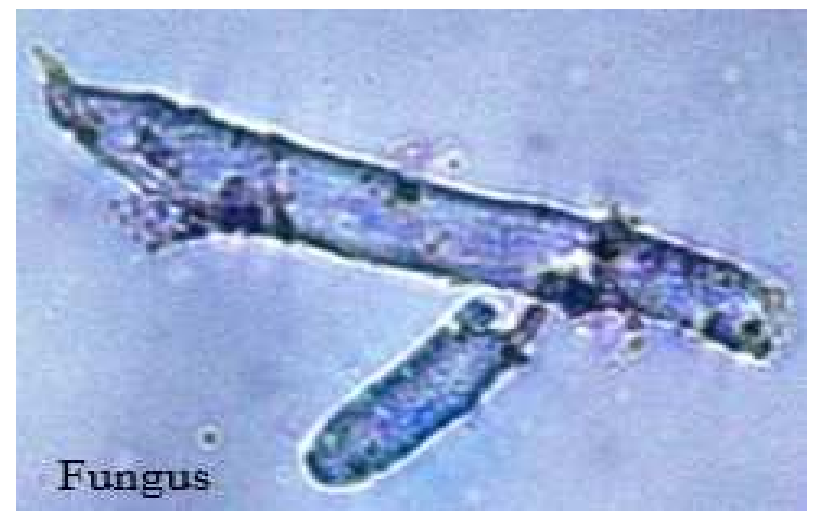

(b)
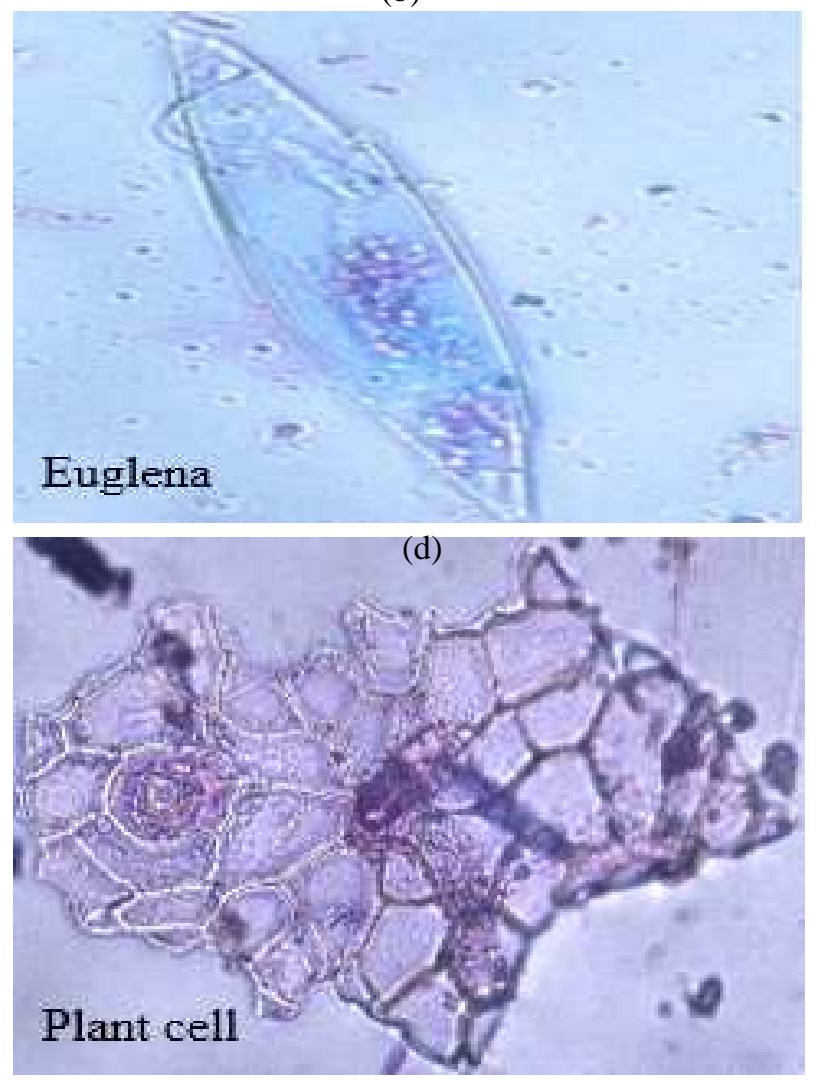

(f)

Plate 1. Different food components of the diet of male and female P. koolooense (a) Animal and e) Algae, (f) Plant matter

matter, (b) Fungi, (c, d

Table 1. Average quantity of different food components in male and female of $P$. koolooense.

\begin{tabular}{|c|c|c|c|c|c|}
\hline & Model animal sex & $\mathbf{N}$ & Mean \pm SD $(\%)$ & $\mathbf{t}$ & Sig. \\
\hline \multirow{2}{*}{ Animal Matter } & Male & 35 & $6.76 \pm 2.5$ & \multirow{2}{*}{-0.597} & \multirow{2}{*}{0.661} \\
\hline & Female & 47 & $7.09 \pm 2.42$ & & \\
\hline \multirow{2}{*}{ Plant Matter } & Male & 35 & $9.29 \pm 2.51$ & \multirow{2}{*}{0.315} & \multirow{2}{*}{0.138} \\
\hline & Female & 47 & $9.13 \pm 2.1$ & & \\
\hline \multirow{2}{*}{ Algae } & Male & 35 & $3.12 \pm 1.0$ & \multirow{2}{*}{-2.066} & \multirow{2}{*}{$0.020 *$} \\
\hline & Female & 47 & $3.74 \pm 1.52$ & & \\
\hline \multirow{2}{*}{ Fungi } & Male & 35 & $0.71 \pm 0.33$ & \multirow{2}{*}{-1.165} & \multirow{2}{*}{0.112} \\
\hline & Female & 47 & $0.85 \pm 0.59$ & & \\
\hline \multirow{2}{*}{ Debris } & Male & 35 & $34.67 \pm 2.79$ & \multirow{2}{*}{0.328} & \multirow{2}{*}{0.149} \\
\hline & Female & 47 & $34.41 \pm 4.06$ & & \\
\hline \multirow{2}{*}{ Unidentified } & Male & 35 & $44.97 \pm 3.07$ & \multirow{2}{*}{2.325} & \multirow{2}{*}{$0.000 *$} \\
\hline & Female & 47 & $42.61 \pm 5.39$ & & \\
\hline
\end{tabular}

* Significant at 0.05 level of significance 
niche of the animal in mountain stream communities.

\section{ACKNOWLEDGEMENT}

Thanks to UGC, New Delhi for providing Rajiv Gandhi National Fellowship (F.1-17.1/2011-12/RGNF-SCUTT-6394) to Shurveer Singh for conducting the research work.

\section{REFERENCES}

Bernardez, C., Freire, J. and Gonzales-Gurriaran, E. (2000). Feeding of the spider crab Maja squinado in rocky subtidal areas of the Ría de Arousa (Northwest Spain). $J$. Mar. Biol. Assoc. U.K. 80: 95-102.

Bryceson, I. and Massinga, A. (2002). Coastal resources and management systems influenced by conflict and migration. Mecufi Mozambique. Ambio, 31: 512-517.

Chande, A.I. and Mgaya, Y.D. (2004). Food habits of blue swimming crab Portunus pelagicus, along the coast of Dar es Salaam. WIOJMS, 3 (1): 37-42.

Chatterjee, S. (2014). Feeding behaviour and functional role of some selected species of brachyuran crabs in nutrient cycle at coastal belt of Midnapore (East), West Bengal, India. JBLS, 5(1):106-129.

Devi, P.L., Nair, D.G. and Joseph, A. (2013). Habitat ecology and food and feeding of the herring bow crab, Varuna litterata (Fabricius, 1798) of Cochin backwaters Kerala India. Arthropods, 2(4): 172188.

Josileen, J. (2011). Food and feeding of the blue swimmer crab, Portunus pelagicus (Linnaeus, 1758) (Decapoda, Brachyura) along the coast of Mandapam, Tamil Nadu, India. Crustaceana, 84 (10): 1169-1180.

Kobayashi, S. (2012). Dietary preference of the potamid crab Geothelphusa dehaani in a mountain stream in Fukuoka, northern Kyushu, Japan. J. Plankton. Res., 3: 36-401.
Mohapatra, A., Mohanty, R.K., Bhatta, K.S., Mohanty, S.K. ( 2005). Food and feeding habits of the mud crab Scylla serrata (Forskal) from Chilika Lagoon. J. Inland Fish. Soc. India, 37 (2), 1-7.

Needham, P.R. and Needham, J.G. (1962). A guide to the study of freshwater biology. 5' Ed. Holden Day Inc. p.108.

Patel, N.M., Chhaya, N.D. and Bhaskaran, M. (1979). Stomach contents of Portunus pelagicus (L.) from AD net catches. Indian J. Mar. Sci., 8: 48-49.

Varadharajan, D. and Pushparajan, N. (2012). Studies on peculiar observations of the food and feeding habits of Painted Pebble crab Leucosia anatum, Southeast coast of India. Int. J. Pharm. Biol. Sci. Arch., 3(5):1170-1173.

Vinagre, A.S., Nunes do Amaral, A.P., Ribarcki, F.P., Fraga da Silveira, E. and Perico, E. (2007). Seasonal variation of energy metabolism in ghost crab O. quadrata at Siriu Beach (Brazil). Com. Biochem. Physiol., 146: 514-519.

Viswanathan, C. and Raffi, S.M. (2015). The natural diet of the mud crab Scylla olivacea (Herbst, 1896) in Pichavaram mangroves, India. Saudi J. Biol. Sci., (Article in press)

Ward H.B. and Whipple, G.C. 1959. Freshwater Biology $2^{\text {nd }}$ Edition, John Wiley and Sons. New York, U.S.A.

Williner, V. and Collins P.A. (2013). Feeding ecology of the freshwater crab Trichodactylus borellianus (Decapoda: Trichodactylidae) in the floodplain of the Paraná River, southern South America. Lat. Am. J. Aquat. Res., 41: 781-792.

Yeo, D.J.C., Ng, P.K.L., Cumberlidge, N., Magalhães, C., Daniels, S.R. and Campos, M.R. (2008). Global diversity of crabs (Crustacea: Decapoda: Brachyura) in freshwater. Hydrobiologia, 595: 275-286. 